\title{
Toward Understanding How Early-Life Stress Reprograms Cognitive and Emotional Brain Networks
}

\author{
Yuncai Chen ${ }^{1}$ and Tallie Z Baram ${ }^{\star, 1,2,3}$ \\ ${ }^{1}$ Department of Pediatrics, University of California, Irvine, CA, USA; ${ }^{2}$ Department of Anatomy/Neurobiology, University of \\ California, Irvine, CA, USA; ${ }^{3}$ Department of Neurology, University of California, Irvine, CA, USA
}

\begin{abstract}
Vulnerability to emotional disorders including depression derives from interactions between genes and environment, especially during sensitive developmental periods. Adverse early-life experiences provoke the release and modify the expression of several stress mediators and neurotransmitters within specific brain regions. The interaction of these mediators with developing neurons and neuronal networks may lead to long-lasting structural and functional alterations associated with cognitive and emotional consequences. Although a vast body of work has linked quantitative and qualitative aspects of stress to adolescent and adult outcomes, a number of questions are unclear. What distinguishes 'normal' from pathologic or toxic stress? How are the effects of stress transformed into structural and functional changes in individual neurons and neuronal networks? Which ones are affected? We review these questions in the context of established and emerging studies. We introduce a novel concept regarding the origin of toxic early-life stress, stating that it may derive from specific patterns of environmental signals, especially those derived from the mother or caretaker. Fragmented and unpredictable patterns of maternal care behaviors induce a profound chronic stress. The aberrant patterns and rhythms of early-life sensory input might also directly and adversely influence the maturation of cognitive and emotional brain circuits, in analogy to visual and auditory brain systems. Thus, unpredictable, stress-provoking early-life experiences may influence adolescent cognitive and emotional outcomes by disrupting the maturation of the underlying brain networks. Comprehensive approaches and multiple levels of analysis are required to probe the protean consequences of early-life adversity on the developing brain. These involve integrated human and animal-model studies, and approaches ranging from in vivo imaging to novel neuroanatomical, molecular, epigenomic, and computational methodologies. Because early-life adversity is a powerful determinant of subsequent vulnerabilities to emotional and cognitive pathologies, understanding the underlying processes will have profound implications for the world's current and future children.
\end{abstract}

Neuropsychopharmacology Reviews (2016) 41, 197-206; doi:10.1038/npp.20 I5.181; published online 29 July 2015

\section{CONCEPTUAL FRAMEWORK (INTRODUCTION)}

Brain maturation involves multiple dynamic processes that are regulated both by genetic factors and environmental input (Huttenlocher and Dabholkar, 1997; Caspi et al, 2003; Levitt, 2003; Gluckman et al, 2008; Martin et al, 2009; Krishnan and Nestler, 2010). Although some of these processes are complete at birth, the early postnatal brain is far from maturity and continues to undergo significant developmental processes; these processes include axonal and dendritic growth, synaptic stabilization, and synaptic pruning (Bale et al, 2010; Regev and Baram, 2014; Hoeijmakers

${ }^{*}$ Correspondence: Professor TZ Baram, Departments of Anatomy/ Neurobiology, Pediatrics and Neurology, University of California-Irvine, Med. Sci. I, ZOT 4475, Irvine, CA 92697-4475, USA, Tel: +1 949824 1131, Fax: +1 949824 1106, E-mail: tallie@uci.edu

Received 15 April 2015; revised 26 May 2015; accepted 19 June 2015; accepted article preview online 24 June 2015 et al, 2015). The perinatal period therefore represents a critical stage of development, rendering the brain particularly vulnerable to organizing (and disorganizing) environmental influences. Indeed, when stress is experienced during this critical early-life period, its impact on brain function can be long-lasting or even permanent, compared with the typically transient effects of stress on the adult brain (Everson-Rose et al, 2003; Wilson et al, 2005; van Os et al, 2010; Provençal and Binder, 2015). Decades of research in the neuroscience and neuroendocrine fields have therefore focused on identifying the mechanisms by which early-life stress regulates brain development. In mammals, including humans, monkeys, and rodents, maternal input has perhaps the most significant influence on the type of environment experienced during development (Bowlby, 1950; Seay, 1962; Baram et al, 2012; Rincón-Cortés and Sullivan, 2014; Kundakovic and Champagne, 2015). In accordance, most animal models of early-life stress have targeted maternal interaction, disturbing either the quantity or quality of maternal care early in life 
(for recent reviews, see Molet et al, 2014; Nishi et al, 2014). Such models have become widely adopted, and from this vast literature it is clear that the ultimate outcome of early-life stress depends on several aspects of the 'stressful' experience: its timing, quality, severity, and duration. Developmental stress may have long-lasting consequences for the structure and function of several brain networks, ultimately modulating the output of multiple emotional, social, and cognitive behaviors. Because mental and neurocognitive illnesses most commonly commence early in life (Kessler et al, 2005; NIH Workgroup, 2009), improved understanding of cognitive and mental illnesses requires knowledge of the type of early-life events that influence cognitive and emotional outcomes, and of the diverse mechanisms by which these influences take place.

Stress is a signal indicating a potential or perceived threat (Calabrese et al, 2007; Joëls and Baram, 2009; Ulrich-Lai and Herman, 2009; McEwen and Gianaros, 2011). Stress is ubiquitous and has high biological significance because it enables rapid, delayed, and often enduring adaptive processes to changing circumstances (Calabrese et al, 2007; Joëls and Baram, 2009; McEwen and Gianaros, 2011). Accordingly, the central nervous system is equipped with several sensing mechanisms to identify stress, as well as processes to respond to stressful signals and be modified by them. Cognitive brain networks, including those centered on the hippocampus and prefrontal cortex regions involved in emotional processes, such as amygdala and the nucleus accumbens, as well as network involved in social behaviors, appear to be particularly vulnerable to the effects of stress (Kim and Diamond, 2002; Joëls and Baram, 2009; Lupien et al, 2009; Malter Cohen et al, 2013; Sandi and Haller, 2015). Important parameters that govern the effects of stress on brain functions include the context and nature of the stress (Zoladz and Diamond, 2008; Joëls and Baram, 2009; McEwen and Gianaros, 2011; Schwabe et al, 2011). Stress is not a unitary entity, but a spectrum of signals that vary both in severity and in duration. Mild or short-lasting stress often enhances memory and decision making by augmenting synaptic plasticity, perhaps reflecting the adaptive importance of remembering threatening or dangerous circumstances (Joëls and Baram, 2009; McEwen and Gianaros, 2011). However, these same mechanisms, when activated intensely or for a prolonged period, may provoke detrimental effects (McEwen and Gianaros, 2011; Maras et al, 2014). In the mature human and rodent, chronic stress often exerts adverse effects on cognitive functions including memory (Kim and Diamond, 2002; McEwen and Gianaros, 2011; Schwabe et al, 2011).

\section{WHAT GENERATES STRESS EARLY IN LIFE? ARE THE CONSEQUENCES A RESULT OF THE STRESS OR OF THE PROVOKING SIGNALS?}

Because of the immaturity of both the 'stress system' and the developing brain, environmental signals that might generate stress in the adult, such as restraint, may not be stressful to the neonate (Levine, 1957; Yi and Baram, 1994; Sullivan et al, 2003). The age-specificity of stress-provoking stimuli has contributed to the concept of a 'stress hypo-responsive period' (see box). A large body of work has since discovered that the developing brain responds to age-specific stress in an age-specific manner, with profound, enduring consequences.

In addition, it was initially assumed that the neonatal period represented generally stable, unidirectional processes of brain development, so that the effects of stress across this period were consistent and cumulative. This assumption has turned out to be largely inaccurate, because even within the early postnatal period, the type and magnitude of stressinduced changes can vary markedly according to precisely when the stress occurs. This notion has been directly tested by studies using a single 24 -h maternal separation (van Oers et al, 1998a, b). For example, a 24-h separation during postnatal days 3-4 leads to a hyper-responsivity to stress later in life, whereas the same procedure just days later (postnatal days 7-8 or 11-12) results in a hypo-responsive stress system. Similar differences have been extended to learning and memory outcomes: maternal separation on postnatal day 3 impairs active avoidance and conditioned freezing, whereas the same stress on postnatal day 9 improves performance in these tasks. These data suggest that the epoch of early postnatal-life comprises complex and overlapping developmental processes, and these may drastically influence the consequences of any experiences or environmental perturbations (Avishai-Eliner et al, 2002).

In addition, the nature of the perturbations that lead to early-life stress seems to govern its consequences. In humans, chronic early-life stress has both physical and emotional components, and the emotional aspects are dominant. In large part, a majority of human early-life stress stems from abnormal patterns of maternal care varying from neglect to inconsistency and lack of sensitivity (Bowlby, 1950; Nelson et al, 2011; Sheridan, McLaughlin, 2014). Complete absence of maternal care results in catastrophic consequences on cognitive and emotional development as found in the studies of orphanage-raised children (Nelson et al, 2011; Hostinar and Gunnar, 2013). To study early-life stress, several rodent models have attempted to recapitulate these conditions by manipulating maternal-pup interactions.

As is the case in humans, maternal care has a critical role in rodent development. Beyond simply providing nutrition and safety in the nest, the dam is critical for providing important sensory signals and relaying environmental cues to the pups (Levine, 1957; Eghbal-Ahmadi et al, 1999; Champagne and Meaney, 2001; Lucassen et al, 2013). Maternal care has been well characterized in rodents and consists of several stereotyped behaviors, including nursing (arched back or low posture) and licking/grooming (Champagne et al, 2003). It follows that perturbation of dam-pup interactions has been viewed as a potent way to manipulate the early-life environment and provoke stress. Simply removing the dam for extended periods of time would lead to hypothermia and starvation, so that many 
TABLE 1 Emotional Outcomes of CES Induced by Limited Bedding/Nesting Environment

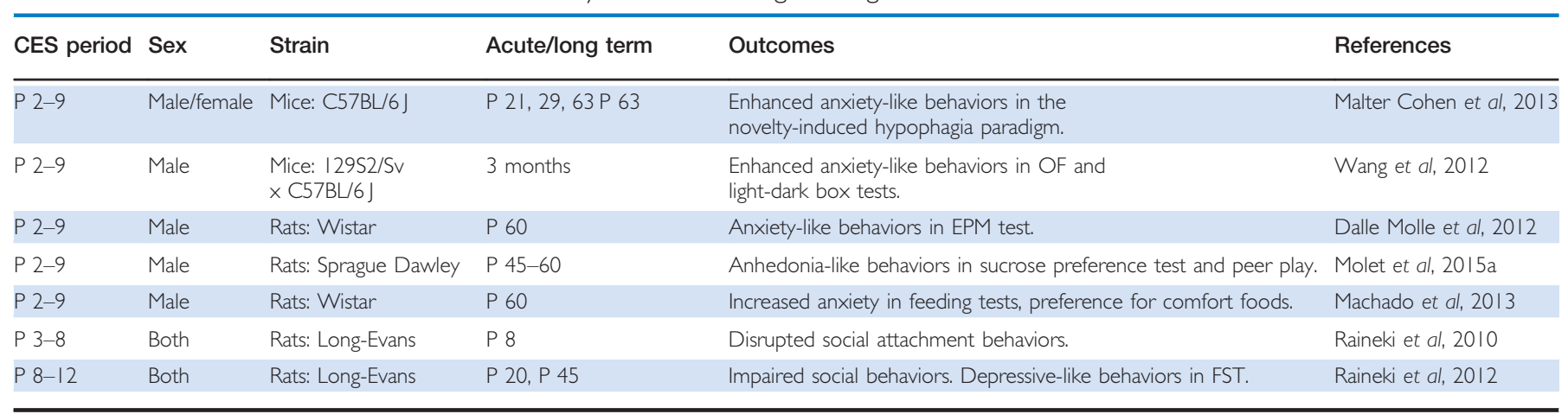

Abbreviations: CES, chronic early-life stress; EPM, elevated plus maze; FST, forced swim test; OF, open field; P, postnatal day.

models have used intermittent maternal deprivation, resulting in intermittent stress, with sometimes variable outcomes (Lehmann and Feldon, 2000; Milstein and Holmes, 2007). An alternative approach has been to provoke chronic, persistent changes in maternal nurturing behaviors by the use of cages with limited nesting and bedding material (Gilles et al, 1996; Molet et al, 2014; Naninck et al, 2015). This 'simulated poverty' induces stress in the dams (Ivy et al, 2008), and alters their behaviors (Ivy et al, 2008; Rice et al, 2008; Rincón-Cortés and Sullivan, 2014). This latter approach has provoked chronic unremitting stress in the pups (Gilles et al, 1996; Ivy et al, 2008; Rice et al, 2008; Moriceau et al, 2009; Raineki et al, 2010; Wang et al, 2011; Molet et al, 2014; Naninck et al, 2015). Notably, there is little evidence of physical stress of the pups, with no hypothermia and minimal weight changes (Molet et al, 2014). Thus, the early-life stress that is engendered seems to be a direct result of the fragmented, unpredictable sensory signals from the mothers (Moriceau et al 2009; Baram et al, 2012; Molet et al, 2014, 2015a). These seem to provoke chronic early-life stress, including persistent elevation of plasma corticosterone and adrenal hypertrophy (Gilles et al, 1996; Rice et al, 2008). Although all of these signs of stress dissipate rapidly when dams and pups are returned to routine cages, the chronic early-life stress promotes protean consequences on cognitive and emotional brain networks and functional outcomes (Tables 1 and 2), as well as brain development, stress sensitivity, and limbic network hyper-excitability (Huang, 2014; Dubé et al, 2015; Table 3).

\section{EMOTIONAL AND SOCIAL CONSEQUENCES OF EARLY-LIFE EXPERIENCE VIA ALTERED STRESS NETWORKS}

Hundreds of human studies over more than six decades have illustrated close statistical associations of early-life adversity and a variety of emotional problems. These publications range from epidemiological studies of famine or war (Brown et al, 1995; Eriksson et al, 2014) to prospective, cross-sectional and case-control analyses (eg, Bremner et al, 1993; Kaplan et al, 2001). Although these associations are compelling, direct causality is difficult to infer in humans, and studies exist that challenge a direct or linear relationship of adversity and, for example, post-traumatic stress disorder (Pratchett and Yehuda, 2011). These difficulties have led to a large body of work using animal models. A variety of prenatal and postnatal stressors have been used in these studies, with a preponderance of studies finding emotional consequences including behaviors that typically signify depression, anxiety, and social isolation. The consequences of early-life (prenatal as well as postnatal) stress on emotional and social behaviors have been a subject of several recent reviews (eg, Sandi and Haller, 2015; Nishi et al, 2014). Here, we summarize in Table form the consequences of chronic early-life adversity provoked by abnormal maternal care in the limited bedding-nesting environment (Gilles et al, 1996; Molet et al, 2014), a model recently adopted and adapted by over 50 laboratories around the world (eg, Raineki et al, 2010; Wang et al, 2011; Bolton et al, 2013; Machado et al, 2013; Maniam et al, 2014; Kohl et al, 2015; Naninck et al, 2015; Table 1).

The mechanisms leading to these profound emotional changes are unclear. Abnormal maturation (Brunson et al, 2005; Bogdan and Hariri, 2012; Burghy et al, 2012; Maras and Baram, 2012) or rewiring of neuronal connectivity in the underlying brain networks (Karsten and Baram, 2013) have been proposed. The nature of these networks is not fully known, but they include amygdala-ventromedial prefrontal cortex circuitry implicated in the regulation of emotion (Burghy et al, 2012). Thus, abnormal maternal care and chronic early-life stress have been shown to result in increased number and function of excitatory synapses to stress-sensitive neurons in hypothalamus (Gunn et al, 2013), whereas reduced excitatory synapse number and function have been reported after augmented maternal care (Korosi et al, 2010). Increased excitatory input may sensitize the central components of the neuroendocrine stress system to subsequent stress, predisposing to stress-related emotional disorders. Other structural changes including stunting, 
TABLE 2 Cognitive Outcomes of CES Induced by Limited Bedding/Nesting Environment

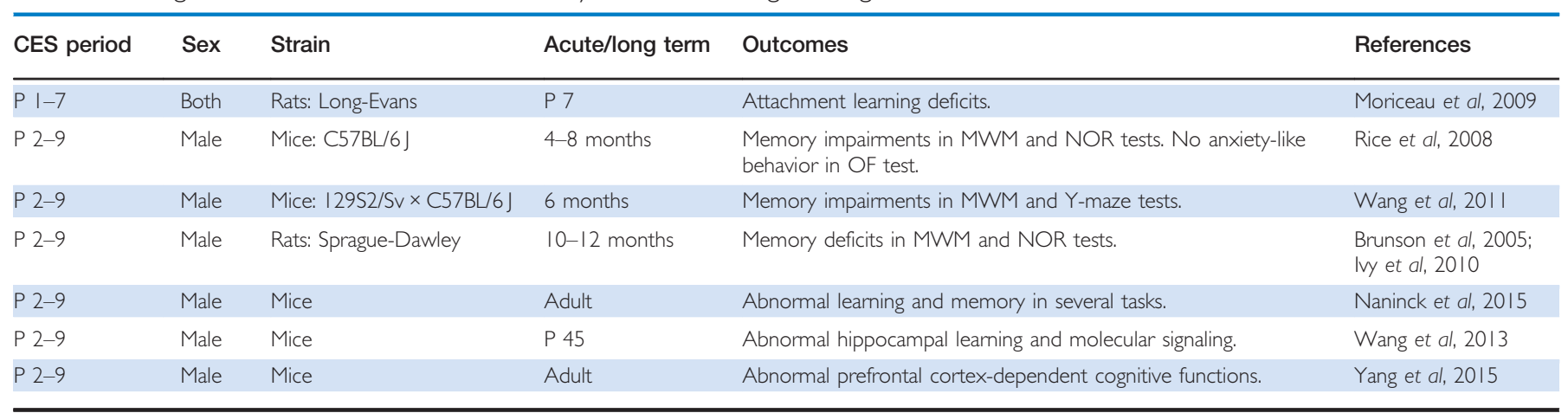

Abbreviations: CES, chronic early-life stress; MWM, Morris water maze; NOR, novel object recognition; OF, open field; $P$, postnatal day.

atrophy, or hypertrophy of dendritic structure and altered synapse number and function might take place in amygdala and hippocampus (Ivy et al, 2010). The resulting changes in intracellular signaling, potentially via calcium-dependent changes, might provide a signal for downstream gene expression effects, maintained via epigenetic alterations of the chromatin (Korosi et al, 2010; Hornung and Heim, 2014; Lewis and Olive, 2014; Turecki, 2014; Szyf, 2015).

\section{COGNITIVE CONSEQUENCES OF EARLY-LIFE EXPERIENCE VIA DISRUPTION OF THE MATURATION OF HIPPOCAMPAL CIRCUITRY}

The basis of the vulnerability of the developing brain to the adverse cognitive effects of early-life stress has been an area of intense research. This vulnerability results in large part from developmental processes that are still taking place during the early-life stress period. Here, we use the hippocampus as a salient example, emphasizing that cognitive functions involve a large set of behaviors enabled by complex and overlapping cortical and subcortical neuronal networks. In rodents, the organization of the hippocampal formation and the limbic circuit, involved in cognitive functions, takes place largely after birth, continuing through the first few weeks of life. In humans, the development of this circuit is characterized by a particularly prolonged trajectory, and refinement of cortical synapses and connectivity patterns continues for years into the adolescent period.

Thus, although the effects of stress on adult cognitive functions such as memory are often reversible, stress that occurs early in life, though amenable to behavioral and pharmacological interventions (eg, Ivy et al, 2010; Shonkoff, 2011), can permanently alter these processes (Brunson et al, 2003). Focusing on chronic and/or severe early-life stress, long-lasting deficits, contextual fear conditioning (Guijarro et al, 2007; Kosten et al, 2007; Oomen et al, 2010) as well as in the Morris watermaze (Oitzl et al, 2000; Huot et al, 2002;
Brunson et al, 2005; Uysal et al, 2005; Aisa et al, 2007; Rice et al, 2008; Ivy et al, 2010; Wang et al, 2012) have been found. Although these tests involve elements of stress and may therefore not be free of confounders, similar defects after early-life stress are found in object recognition (Brunson et al, 2005; Aisa et al, 2007; Kosten et al, 2007; Rice et al, 2008; Ivy et al, 2010; Hulshof et al, 2011) and object location (Molet et al, 2015b).

How might early-life stress impair memory and other cognitive functions? Early in life, stress may both interfere with the normal construction and maturation of cortical and hippocampal synaptic connections as well as promote their destruction (Kehoe and Bronzino, 1999; Brunson et al, 2005; Cui et al, 2006; Radley et al, 2008; Maras and Baram, 2012). In mature brain, stress induces structural changes that progress with the duration, severity, and developmental timing of the stress. Modifications of the synaptic machinery take place within minutes (Chen et al, 2008, 2013) and chronic stress leads to remodeling of dendritic branches (Kim and Diamond, 2002; McEwen, 2012). Dendritic integrity requires the presence of functional excitatory synapses, which are located primarily on dendritic spines (Bourne and Harris, 2008; Holtmaat and Svoboda, 2009; Kasai et al, 2010). Rapid, stress-induced dendritic spine loss has been found in the distribution of eventual dendritic atrophy in adult hippocampus (Pawlak et al, 2005; Diamond et al, 2006; Chen et al, 2008, 2013), suggesting that they are related. Importantly, the number and shape of synapsebearing spines are dynamic (Bourne and Harris, 2008; Holtmaat and Svoboda, 2009; Kasai et al, 2010) and are regulated by factors including neurotransmitters, growth factors, and hormones that, in turn, are governed by environmental signals, including stress (Segal, 2010; Liston and Gan, 2011). Thus, a derangement of spine dynamics may provide a mechanism for stress-induced impairment of synaptic function, followed by dendritic loss and cognitive impairments.

After chronic early-life stress in rodents, impoverished dendritic trees and reduced hippocampal volume have been described (Brunson et al, 2005; Ivy et al, 2010; Molet et al, 
TABLE 3 Structural, Functional and Gene Expression Changes Provoked by CES Induced by a Limited Bedding/Nesting Environment

\begin{tabular}{|c|c|c|c|c|c|}
\hline $\begin{array}{l}\text { CES } \\
\text { period }\end{array}$ & Sex & Species/strain & $\begin{array}{l}\text { Acute/long } \\
\text { term }\end{array}$ & Outcomes & References \\
\hline \multicolumn{6}{|c|}{ Stress system perturbations } \\
\hline
\end{tabular}

Structural and functional brain changes

\begin{tabular}{|c|c|c|c|c|c|}
\hline $\mathrm{P} \mid-7$ & Both & Rats: Long-Evans & P 7 & Amygdala-locus ceruleus-olfactory bulb network perturbations. & Moriceau et al, 2009 \\
\hline P 2-9 & Both & $\begin{array}{l}\text { Mice: C57BL/6 J } \times \\
\text { [29 Sv-Sv] }\end{array}$ & $P \mid 8-26$ & $\begin{array}{l}\text { Enhanced glutamatergic drive onto CRH neurons of the } \\
\text { hypothalamus. Astrocytic glutamate reuptake impairments. }\end{array}$ & Gunn et al, 2013 \\
\hline P 2-9 & Male & Rats: Sprague-Dawley & $10-12$ months & $\begin{array}{l}\text { Dendritic atrophy of CAI, CA3 pyramidal cells; mossy fiber } \\
\text { sprouting. Synaptic plasticity defects in CAI, CA3. }\end{array}$ & $\begin{array}{l}\text { Brunson et al, } 2005 \\
\text { Ivy et al, } 2010\end{array}$ \\
\hline P 2-9 & Both & Rats: Sprague-Dawley & 14-40 days & $\begin{array}{l}\text { Hyper-excitability during chronic EEG recording, age specific- } \\
\text { seizures (infantile spasm-like) in most; spontaneous seizures } \\
\text { (epilepsy) in a minority. }\end{array}$ & Dube et al, 2015 \\
\hline \multicolumn{6}{|c|}{ Gene-expression changes } \\
\hline P 2-9 & Both & Rats: Sprague-Dawley & P 9 & $\begin{array}{l}\text { Transiently reduced CRH mRNA in PVN and CRFI mRNA in } \\
\text { hippocampal CAI, DG. Reduced CRH receptor binding in pituitary. } \\
\text { Reduced GR mRNA expression in PVN and frontal cortex. }\end{array}$ & Avishai-Eliner et al, $200 \mathrm{I}$ \\
\hline P 2-9 & Male & Mice: C57BL/6 J & $4-8$ months & Reduced CRH mRNA expression in the PVN. & Rice et al, 2008 \\
\hline P 2-9 & Both & $\begin{array}{l}\text { Mice: C57BL/6 J x } \\
\text { I29 Sv-Sv] }\end{array}$ & Adult & Upregulated CRH expression in the PVN. & Gunn et al, 2013 \\
\hline
\end{tabular}

Structural and functional changes

\begin{tabular}{|c|c|c|c|c|c|}
\hline P 2-9 & Male & Mice & Adult & Altered neurogenesis and survival of newborn cells. & Naninck et al, 2015 \\
\hline P $2-12$ & Male & Mice & P 26, P33, P68 & Enhanced and aberrant amygdala activity. & Malter Cohen et al, 2013 \\
\hline
\end{tabular}

Abbreviations: BDNF, brain-derived neurotrophic factor; CAI and CA3, comum Ammonis regions of the hippocampus I and 3; CES, chronic early-life stress; CRH, corticotropin releasing hormone; CRHI, CRH receptor I; DG, dentate gyrus; EEG, electroencephalography; GR, glucocorticoid receptor; MR, mineralocorticoid receptor; $\mathrm{P}$, postnatal day; PVN, paraventricular nucleus of hypothalamus.

2015b), and similar dendritic changes were found in the prefrontal cortex (Radley et al, 2008; Yang et al, 2015). In humans, chronic early-life stress such as rearing in orphanages promotes reduced volume of the cortex (especially prefrontal) as well as hippocampus and the latter correlates with stress duration (Hodel et al, 2015). The cortex is composed of several components including cell bodies, intercellular space, and branched dendritic tree. Indeed, the dendrites comprise $\sim 42 \%$ of cortical volume (Paus, 2009). Therefore, in view of the correlated dendritic impoverishment and cellular volume loss in rodents, it is likely cortical, and hippocampal volume reduction in human adolescents and adults exposed to early-life adversity might derive from abnormal growth and branching of synapse-carrying neuronal dendrites. The reduced synaptic number in hippocampus and frontal cortex, in turn, may contribute to functional deficits (Brunson et al, 2005; Radley et al, 2008; Ivy et al, 2010; Schmidt et al, 2011; Maras and Baram, 2012).
This poor dendritic growth and branching and/or dendritic atrophy secondary to a loss of functional synapses on destroyed dendritic spines (Diamond et al, 2006; Chen et al, 2008; Lin and Koleske, 2010) may progress with age (Brunson et al, 2005; Ivy et al, 2010). Support for this possibility emerges from studies using transgenic mice (Wang et al, 2011, 2012). Specifically, mice with a conditional knockout of the CRFR1 gene were resistant to the adult cognitive defects that follow chronic early-life stress. The early-life stress took place during the first postnatal week, prior to the repression of the CRFR1 receptor via a CaM Kinase II mechanism (the latter is expression commencing P5-10, with full maturation by P20; Wang et al, 2011). Thus, whereas CRFR1 receptors were still expressed during the first 10 days of life, the period of chronic stress, their elimination later in life was protective, suggesting that the cognitive deficits require progressive processes beyond the stress period. In addition, in wild-type 

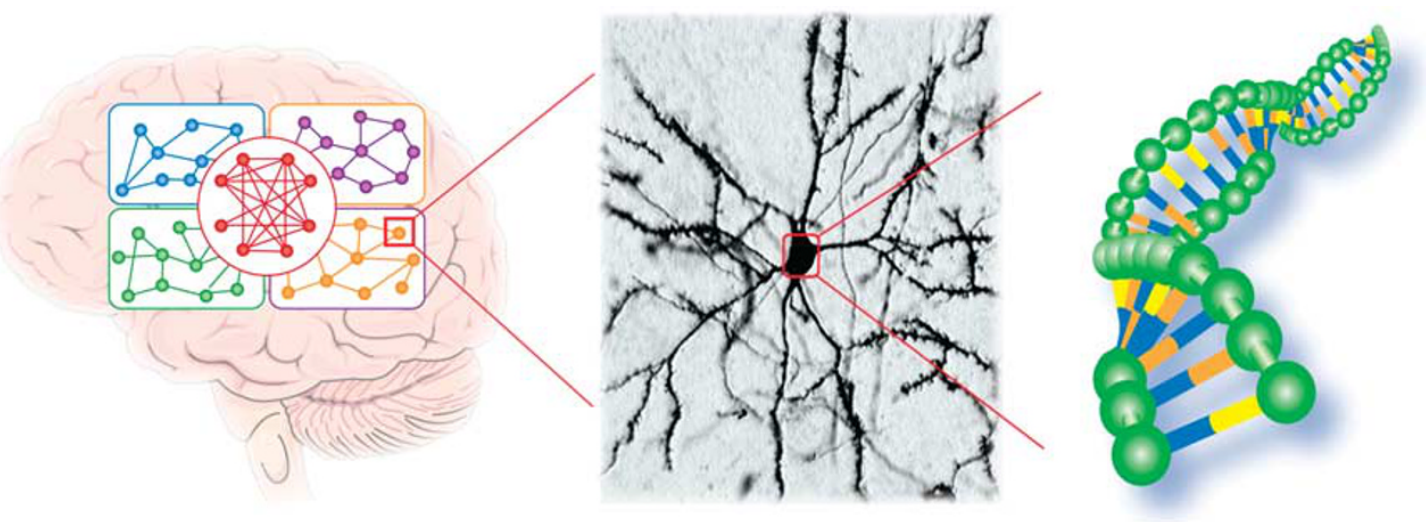

Figure 1. A schematic representation of the multiple levels of analysis that are required to appreciate the reprogramming of the brain by early-life experiences, including stress. Left: the brain is composed of a number of discrete yet overlapping and interacting networks. Center: neurons, the components of these networks, have a remarkable complexity of their structure, supporting profound functional complexity. Right: neuronal structure and function are governed by the repertoire of genes encoded by DNA, the regulated expression of these genes, and the orchestration of the location and function of the gene products in time and space.

mice and rats, a progressive emergence of cognitive problems and a progression of hippocampal dendritic injury support the idea that chronic early-life stress induces progressive functional and structural changes in the hippocampus. In contrast, a majority of the injury likely takes place within a 'critical' or 'sensitive' period early in life (Regev and Baram, 2014), because pharmacological interventions immediately following the early-stress period (Ivy et al, 2010) reversed the effect of such stress, whereas the same manipulation several months later had only a partial effect (Ivy et al, unpublished observations). Epidemiological studies in humans are also suggestive of a progressive injury: cognitive problems in individuals with surrogate markers of chronic stress during childhood emerge during middle age and are a risk factor for early dementia (Kaplan et al, 2001). In contrast, studies on children subjected to early-life emotional deprivation followed by environmental enrichment (Nelson et al, 2007; Hostinar and Gunnar, 2013) suggest that intervention beyond the first 2-3 years of life is less effective, supporting a sensitive or critical period for the major effects of early-life stress (Figure 1 in Regev and Baram, 2014). Abnormal development and progressive injury following early-life stress are not mutually exclusive, as impairments of cognitive functions over the lifetime may reflect cumulative effects of both early and continuing processes (McEwen 1999, 2012; Ulrich-Lai and Herman, 2009). Obviously, if the effects of early-life stress were to progress beyond the initial period, this would provide an important more protracted window for intervention.

\section{THE TOOLBOX OF EARLY-LIFE STRESS}

During stress, synapses in several brain regions are impacted by a cocktail of stress mediators with distinct and concerted actions and mechanisms. Glucocorticoids are the canonical stress hormones that are released peripherally in response to stress. They can have broad impacts on brain function (Drost et al, 2008; Ulrich-Lai and Herman, 2009; McEwen, 2012), including affecting neuronal structure such as dendritic arborization and the dynamics of dendritic spines (eg, Magariños and McEwen, 1995; Jafari et al, 2012; Liston et al, 2013). Thus, poor dendritic growth and branching may be a result of abnormal levels of glucocorticoids and their actions on cognate receptors (GR) (Alfarez et al, 2009; Liston and Gan, 2011). Alternatively, dendrites may atrophy, secondary to a loss of functional synapses on the destroyed dendritic spines (Lin and Koleske, 2010). In support of this idea, dendritic spines and novel mechanisms for these changes are emerging, including glucocorticoid receptor-mediated induction of actin-binding proteins (Liston and Gan, 2011).

However, glucocorticoids are only one of the molecular instruments impinging on synapses and dendritic spines during early-life stress. Neurotransmitters and neuropeptides, especially $\mathrm{CRH}$, may contribute to both aberrant growth and/or exuberant pruning of dendrites and dendritic spines. In the case of $\mathrm{CRH}$, the peptide is synthetized locally in the hippocampus, amygdala, bed nucleus of the stria terminalis, and cortex (Joëls and Baram, 2009). Increased $\mathrm{CRH}$ expression has been found in hippocampus (Ivy et al, 2010) and amygdala (Dube et al, 2015) after early-life stress. $\mathrm{CRH}$ is released during stress in several of brain regions as well as locus ceruleus (Rozendaal et al, 2002; Chen et al, 2004a; Van Bockstaele and Valentino, 2013). The peptide acts on CRH receptors within these regions (Chen et al, 2000, Van Pett et al, 2000; Refojo et al, 2011; Van Bockstaele and Valentino, 2013), and these receptors often reside on dendritic spines (Chen et al, 2004a, 2012). CRH has potent effects on dendritic spines and synapse integrity, effects that are mediated via actin remodeling (Chen et al, 2013), calcium-dependent calpain activation (Andres et al, 2013) and likely additional mechanisms. Chronic exposure to CRH may provoke dendritic stunting and atrophy (Chen et al, 2004b). Thus, abnormal, high levels of CRH may impair 
dendritic arborization or contribute to dendritic pruning, perhaps in concert with glucocorticoid actions (Joëls and Baram, 2009).

\section{CRUCIAL QUESTIONS AND FUTURE RESEARCH DIRECTIONS}

The study of early-life stress provides a window into the understanding of normal adaptation, as well as the basis of resilience and vulnerability to emotional and cognitive disorders throughout life. Although much has been accomplished, several conceptual challenges remain. These include:

a. Identifying and defining genetic pre-dispositions to the impact of early-life stress. Although early-life adversity is a major risk factor for later pathology, there is a substantial variability in the outcome of early stress. What genetic (or epigenetic) factors impart vulnerability or resilience to the effects of early-life stress?

b. Identifying interactions between stress early in life and those stresses experienced later in life. Individuals exposed to early stress are likely to experience stress throughout their lifespan. How do early stressful experiences impact the consequences of stress experienced later in life? Are there other sensitive periods, such as adolescence, when the brain is particularly vulnerable to stress?

c. Elucidating the nature and underlying biology of sexspecific consequences of early-life stress. Human epidemiological data indicate that stress-related psychopathologies are more prevalent in females, yet there is a relative dearth of animal models studying how sex modulates vulnerability to the effects of early stress. How do genetic and hormonal sex differences contribute to sex-specific consequences of early-life stress?

d. Addressing the formidable issue of the generalization and translation of rodent studies to the human condition. Rodent models have proven extremely useful in describing the consequences of early-life stress on brain development and identifying mechanisms involved. However, it is crucial to exert care when applying these findings and theories back to the human condition.

Novel and exciting tools should enable addressing the conceptual above and the daunting-associated technical challenges. Transgenic mice with visible and controllable specific cell populations now offer tremendous opportunities for dissecting the roles of specific neurons and circuits. However, their use requires ascertainment of the specificity of these lines (Chen et al, 2015; Lammel et al, 2015). A clearer understanding of the roles of several individual stress mediators, including not only glucocorticoids but also $\mathrm{CRH}$, other neuropeptides, and novel molecules, is emerging (Joëls and Baram, 2009). The individual and concerted actions of these mediators during sensitive postnatal periods should be probed, focusing on their effects on individual genes and neurons as well as on gene networks and ultimately brain networks that underlie normal and pathological functions.

\section{THE CONCEPT OF THE 'STRESS HYPO-RESPONSIVE PERIOD'}

Initial work on the ontogeny of the neuroendocrine stress response system indicated that the first 2 weeks of life in rodents (postnatal days $4-14$ in rats; $1-12$ in mice), the HPA system is relatively unresponsive to stress (termed the 'stress hypo-responsive period' or 'SHRP'). This characterization is based on low basal corticosterone levels, reduced sensitivity to $\mathrm{CRH}$, and the apparent lack of a stress response to a variety of 'typical' stressors during this age. The SHRP likely reflects the still ongoing maturation of the HPA axis, and this reduction in HPA tone has been hypothesized to protect against the deleterious effects of glucocorticoids on brain development. Importantly, the initial concept of a SHRP has been proven to not fully represent the stress status of immature brains. In humans, stress responses to pain exist throughout the neonatal period. In rodents, immature pups have $300-400 \%$ increases in plasma corticosterone levels in response to age-appropriate stressors, that is, maternal separation or hypothermia. These hormonal responses are mediated by stress-induced activation of $\mathrm{CRH}$ release and associated with stress-induced enhancement of $\mathrm{CRH}$ expression in hypothalamic PVN neurons. Thus, rather than being unresponsive, the developing stress system seems to be tuned specifically to the types of stress that may be relevant to the early-life period.

\section{FUNDING AND DISCLOSURE}

The authors declare no conflict of interest.

\section{ACKNOWLEDGMENTS}

This work was supported by the National Institute of Health grants P50 MH096889, R01 NS028912, R01 MH073136. We thank Barbara Cartwright for editorial help.

\section{REFERENCES}

Aisa B, Tordera R, Lasheras B, Del Río J, Ramírez MJ (2007). Cognitive impairment associated to HPA axis hyperactivity after maternal separation in rats. Psychoneuroendocrinology 32: 256-266.

Alfarez DN, De Simoni A, Velzing EH, Bracey E, Joëls M, Edwards FA et al (2009). Corticosterone reduces dendritic complexity in developing hippocampal CA1 neurons. Hippocampus 19: 828-836.

Andres AL, Regev L, Phi L, Seese RR, Chen Y, Gall CM et al (2013). NMDA receptor activation and calpain contribute to disruption of dendritic spines by the stress neuropeptide CRH. J Neurosci 33: 16945-16960.

Avishai-Eliner S, Brunson KL, Sandman CA, Baram TZ (2002). Stressed-out, or in (utero)? Trends Neurosci 25: 518-524.

Avishai-Eliner S, Gilles EE, Eghbal-Ahmadi Y, Bar-El Y, Baram T (2001). Altered regulation of gene and protein expression of hypothalamic-pituitary-adrenal axis components in an immature rat model of chronic stress. J Neuroendocrinol 13: 799-807.

Baram TZ, Davis EP, Obenaus A, Sandman CA, Small SL, Solodkin A et al (2012). Fragmentation and unpredictability of early-life experience in mental disorders. Am J Psychiatry 169: 907-915.

Bale TL, Baram TZ, Brown AS, Goldstein JM, Insel TR, McCarthy MM et al (2010). Early life programming and neurodevelopmental disorders. Biol Psychiatry 68: 314-319.

Bogdan R, Hariri AR (2012). Neural embedding of stress reactivity. Nat Neurosci 15: 1605-1607. 
Bolton JL, Huff NC, Smith SH, Mason SN, Foster WM, Auten RL et al (2013). Maternal stress and effects of prenatal air pollution on offspring mental health outcomes in mice. Environ Health Perspect 121: 1075-1082.

Bowlby $J$ (1950). Research into the origins of delinquent behaviour. Br Med $J$ 1: $570-573$.

Bourne JN, Harris KM (2008). Balancing structure and function at hippocampal dendritic spines. Annu Rev Neurosci 31: 47-67.

Bremner JD, Southwick SM, Johnson DR, Yehuda R, Charney DS (1993). Childhood physical abuse and combat-related posttraumatic stress disorder in Vietnam veterans. Am J Psychiatry 150: 235-239.

Brown AS, Susser ES, Lin SP, Neugebauer R, Gorman JM (1995). Increased risk of affective disorders in males after second trimester prenatal exposure to the Dutch hunger winter of 1944-45. Br J Psychiatry 166: 601-606.

Brunson KL, Chen Y, Avishai-Eliner S, Baram TZ (2003). Stress and the developing hippocampus: a double-edged sword? Mol Neurobiol 27: 121-136.

Brunson KL, Kramár E, Lin B, Chen Y, Colgin LL, Yanagihara TK, Lynch G, Baram TZ et al (2005). Mechanisms of late-onset cognitive decline after early-life stress. J Neurosci 25: 9328-9338.

Burghy CA, Stodola DE, Ruttle PL, Molloy EK, Armstrong JM, Oler JA et al (2012). Developmental pathways to amygdala-prefrontal function and internalizing symptoms in adolescence. Nat Neurosci 15: 1736-1741.

Calabrese EJ, Bachmann KA, Bailer AJ, Bolger PM, Borak J, Cai L et al (2007). Biological stress response terminology: integrating the concepts of adaptive response and preconditioning stress within a hormetic dose-response framework. Toxicol Appl Pharmacol 222: 122-128.

Caspi A, Sugden K, Moffitt TE, Taylor A, Craig IW, Harrington H et al (2003). Influence of life stress on depression: moderation by a polymorphism in the 5-HTT gene. Science 301: 386-389.

Champagne F, Meaney MJ (2001). Like mother, like daughter: evidence for nongenomic transmission of parental behavior and stress responsivity. Prog Brain Res 133: 287-302.

Champagne FA, Francis DD, Mar A, Meaney M J (2003). Variations in maternal care in the rat as a mediating influence for the effects of environment on development. Physiol Behav 79: 359-371.

Chen Y, Brunson K, Müller MB, Cariaga W, Baram TZ (2000). Immunocytochemical distribution of corticotropin-releasing hormone receptor type-1 (CRF1)-like immunoreactivity in the mouse brain: light microscopy analysis using an antibody directed against the C-terminus. J Comp Neurol 420: 305-323.

Chen Y, Brunson KL, Adelmann G, Bender RA, Frotscher M, Baram TZ (2004a). Hippocampal corticotropin releasing hormone: pre- and postsynaptic location and release by stress. Neuroscience 126: 533-540.

Chen Y, Bender RA, Brunson KL, Pomper JK, Grigoriadis DE, Wurst W et al (2004b). Modulation of dendritic differentiation by corticotropin-releasing factor in the developing hippocampus. Proc Natl Acad Sci USA 101: 15782-15787.

Chen Y, Dubé CM, Rice CJ, Baram TZ (2008). Rapid loss of dendritic spines after stress involves derangement of spine dynamics by corticotropin-releasing hormone. J Neurosci 28: 2903-2911.

Chen Y, Andres AL, Frotscher M, Baram TZ (2012). Tuning synaptic transmission in the hippocampus by stress: the CRH system. Front Cell Neurosci 6: 13.

Chen Y, Kramár EA, Chen LY, Babayan AH, Andres AL, Gall CM et al (2013). Impairment of synaptic plasticity by the stress mediator $\mathrm{CRH}$ involves selective destruction of thin dendritic spines via RhoA signaling. Mol Psychiatry 18: 485-496.

Chen Y, Molet J, Gunn BB, Baram TZ (2015). Diversity of CRH expression patterns in transgenic mouse lines of $\mathrm{CRH}$ - expression neuron reporters. Soc Neurosci Abst submitted.

Cui M, Yang Y, Yang J, Zhang J, Han H, Ma W et al (2006). Enriched environment experience overcomes the memory deficits and depressive-like behavior induced by early life stress. Neurosci Lett 404: 208-212.

Dalle Molle R, Portella AK, Goldani MZ, Kapczinski FP, Leistner-Segal S, Salum GA et al (2012). Associations between parenting behavior and anxiety in a rodent model and a clinical sample: relationship to peripheral BDNF levels. Trans/ Psychiatry 2: e195.

Diamond DM, Campbell AM, Park CR, Woodson JC, Conrad CD, Bachstetter AD et al (2006). Influence of predator stress on the consolidation versus retrieval of long-termspatial memory and hippocampal spinogenesis. Hippocampus 16: 571-576.

Droste SK, de Groote L, Atkinson HC, Lightman SL, Reul JM, Linthorst AC (2008). Corticosterone levels in the brain show a distinct ultradian rhythm but a delayed response to forced swim stress. Endocrinology 149: 3244-3253.

Dubé CM, Molet J, Singh-Taylor A, Ivy A, Maras PM, Baram TZ (2015). Hyperexcitability and epilepsy generated by chronic early-life stress. Neurobio/ Stress 2 : 10-19.

Eghbal-Ahmadi M, Avishai-Eliner S, Hatalski CG, Baram TZ (1999). Differential regulation of the expression of corticotropin-releasing factor receptor type 2
(CRF2) in hypothalamus and amygdala of the immature rat by sensory input and food intake. J Neurosci 19: 3982-3991.

Eriksson M, Räikkönen K, Eriksson JG (2014). Early life stress and later health outcomes-findings from the Helsinki Birth Cohort Study. Am J Hum Biol 26: 111-116.

Everson-Rose SA, Mendes de Leon CF, Bienias JL, Wilson RS, Evans DA (2003) Early life conditions and cognitive functioning in later lifeAm $J$ Epidemiol 158: 1083-1089.

Gilles EE, Schultz L, Baram TZ (1996). Abnormal corticosterone regulation in an immature rat model of continuous chronic stress. Pediatr Neurol 15: 114-119.

Gluckman PD, Hanson MA, Cooper C, Thornburg KL (2008). Effect of in utero and early-life conditions on adult health and disease. N Engl J Med 359: 61-73.

Gunn BG, Cunningham L, Cooper MA, Corteen NL, Seifi M, Swinny JD et al (2013). Dysfunctional astrocytic and synaptic regulation of hypothalamic glutamatergic transmission in a mouse model of early-life adversity: relevance to neurosteroids and programming of the stress response. J Neurosci 33: 19534-19554.

Guijarro JZ, Tiba PA, Ferreira TL, Kawakami SE, Oliveira MG, Suchecki D (2007). Effects of brief and long maternal separations on the HPA axis activity and the performance of rats on context and tone fear conditioning. Behav Brain Res 184: 101-108.

Hodel AS, Hunt RH, Cowell RA, Van Den Heuvel SE, Gunnar MR, Thomas KM (2015). Duration of early adversity and structural brain development in postinstitutionalized adolescents. Neuroimage 105: 112-119.

Hoeijmakers L, Lucassen PJ, Korosi A (2015). The interplay of early-life stress, nutrition, and immune activation programs adult hippocampal structure and function. Front Mol Neurosci 7: 103.

Holtmaat A, Svoboda K (2009). Experience-dependent structural synaptic plasticity in the mammalian brain. Nat Rev Neurosci 10: 647-658.

Hornung OP, Heim CM (2014). Gene-environment interactions and intermediate phenotypes: early trauma and depression. Front Endocrinol (Lausanne) 5: 14

Hostinar CE, Gunnar MR (2013). The developmental effects of early life stress: an overview of current theoretical frameworks. Curr Dir Psychol Sci 22: 400-406.

Huang LT (2014). Early-life stress impacts the developing hippocampus and primes seizure occurrence: cellular, molecular, and epigenetic mechanisms. Front $\mathrm{Mol}$ Neurosci 7: 8.

Hulshof HJ, Novati A, Sgoifo A, Luiten PG, den Boer JA, Meerlo P (2011). Maternal separation decreases adult hippocampal cell proliferation and impairs cognitive performance but has little effect on stress sensitivity and anxiety in adult Wistar rats. Behav Brain Res 216: 552-560.

Huot RL, Plotsky PM, Lenox RH, McNamara RK (2002). Neonatal maternal separation reduces hippocampal mossy fiber density in adult Long Evans rats. Brain Res 950: 52-63.

Huttenlocher PR, Dabholkar AS (1997). Regional differences in synaptogenesis in human cerebral cortex. J Comp Neurol 387: 167-178.

Ivy AS, Brunson KL, Sandman C, Baram TZ (2008). Dysfunctional nurturing behavior in rat dams with limited access to nesting material: a clinically relevant model for early-life stress. Neuroscience 154: 1132-1142.

Ivy AS, Rex CS, Chen Y, Dubé C, Maras PM, Grigoriadis DE et al (2010). Hippocampal dysfunction and cognitive impairments provoked by chronic earlylife stress involve excessive activation of $\mathrm{CRH}$ receptors. J Neurosci 30: 13005-13015.

Jafari M, Seese RR, Babayan AH, Gall CM, Lauterborn JC (2012). Glucocorticoidreceptors are localized to dendritic spines and influence local actin signaling. $\mathrm{Mol}$ Neurobiol 46: 304-315.

Joëls M, Baram TZ (2009). The neuro-symphony of stress. Nat Rev Neurosci 10: 459-466.

Kaplan GA, Turrell G, Lynch JW, Everson SA, Helkala EL, Salonen JT (2001). Childhood socioeconomic position and cognitive function in adulthood. Int $J$ Epidemiol 30: 256-263.

Karsten CA, Baram TZ (2013). How does a neuron "know" to modulate its epigenetic machinery in response to early-life environment/experience? Front Psychiatry 4: 89.

Kasai H, Fukuda M, Watanabe S, Hayashi-Takagi A, Noguchi J (2010). Structural dynamics of dendritic spines in memory and cognition. Trends Neurosci 33: 121-129.

Kehoe P, Bronzino JD (1999). Neonatal stress alters LTP in freely moving male and female adult rats. Hippocampus 9: 651-658.

Kessler RC, Demler O, Frank RG, Olfson M, Pincus HA, Walters EE et al (2005). Prevalence and treatment of mental disorders, 1990 to 2003. N Engl J Med 352 2515-2523.

Kim JJ, Diamond DM (2002). The stressed hippocampus, synaptic plasticity and lost memories. Nat Rev Neurosci 3: 453-462.

Kohl C, Wang XD, Grosse J, Fournier C, Harbich D, Westerholz S et al (2015). Hippocampal neuroligin-2 links early-life stress with impaired social recognition and increased aggression in adult mice. Psychoneuroendocrinology 55: 128-143. 
Korosi A, Shanabrough M, McClelland S, Liu ZW, Borak E, Gao XB et al (2010). Early-life experience reduces excitation to stress-responsive hypothalamic neurons and reprograms the expression of corticotropin-releasing hormone. J Neurosci 30: 703-713

Kosten TA, Karanian DA, Yeh J, Haile CN, Kim JJ, Kehoe P et al (2007). Memory impairments and hippocampal modifications in adult rats with neonatal isolation stress experience. Neurobiol Learn Mem 88: 167-176.

Krishnan V, Nestler EJ (2010). Linking molecules to mood: new insight into the biology of depression. Am J Psychiatry 167: 1305-1320.

Kundakovic M, Champagne FA (2015). Early-life experience, epigenetics, and the developing brain. Neuropsychopharmacology 40: 141-153.

Lammel S, Steinberg EE, Földy C, Wall NR, Beier K, Luo L et al (2015). Diversity of transgenic mouse models for selective targeting of midbrain dopamine neurons. Neuron 85: 429-438.

Lehmann J, Feldon J (2000). Long-term biobehavioral effects of maternal separation in the rat: consistent or confusing? Rev Neurosci 11: 383-408.

Levine S (1957). Infantile experience and resistance to physiological stress. Science 126: 405.

Levitt $P$ (2003). Structural and functional maturation of the developing primate brain. $J$ Pediatr 143: S35-S45.

Lewis CR, Olive MF (2014). Early-life stress interactions with the epigenome: potential mechanisms driving vulnerability toward psychiatric illness. Behav Pharmacol 25: 341-351.

Lin YC, Koleske AJ (2010). Mechanisms of synapse and dendrite maintenance and their disruption in psychiatric and neurodegenerative disorders. Annu Rev Neurosci 33: 349-378.

Liston C, Gan WB (2011). Glucocorticoids are critical regulators of dendritic spine development and plasticity in vivo. Proc Natl Acad Sci USA 108: 16074-16079.

Liston C, Cichon JM, Jeanneteau F, Jia Z, Chao MV, Gan WB (2013). Circadian glucocorticoid oscillations promote learning-dependent synapse formation and maintenance. Nat Neurosci 16: 698-705.

Lucassen PJ, Naninck EF, van Goudoever JB, Fitzsimons C, Joels M, Korosi A (2013). Perinatal programming of adult hippocampal structure and function; emerging roles of stress, nutrition and epigenetics. Trends Neurosci 36: 621-631.

Lupien SJ, McEwen BS, Gunnar MR, Heim C (2009). Effects of stress throughout the lifespan on the brain, behaviour and cognition. Nat Rev Neurosci 10: 434-445.

Machado TD, Dalle Molle R, Laureano DP, Portella AK, Werlang IC, Benetti Cda S et al (2013). Early life stress is associated with anxiety, increased stress responsivity and preference for "comfort foods" in adult female rats. Stress 16 : 549-556.

Magariños AM, McEwen BS (1995). Stress-induced atrophy of apical dendrites of hippocampal CA3c neurons: involvement of glucocorticoid secretion and excitatory amino acid receptors. Neuroscience 69: 89-98.

Malter Cohen M, Jing D, Yang RR, Tottenham N, Lee FS, Casey BJ (2013). Early-life stress has persistent effects on amygdala function and development in mice and humans. Proc Natl Acad Sci USA 110: 18274-18278.

Maniam J, Antoniadis C, Morris MJ (2014). Early-life stress, hpa axis adaptation, and mechanisms contributing to later health outcomes. Front Endocrinol (Lausanne) 5: 73 .

Maras PM, Baram TZ (2012). Sculpting the hippocampus from within: stress, spines, and $\mathrm{CRH}$. Trends Neurosci 35: 315-324.

Maras PM, Molet J, Chen Y, Rice C, Ji SG, Solodkin A et al (2014). Preferential loss of dorsal-hippocampus synapses underlies memory impairments provoked by short, multimodal stress. Mol Psychiatry 19: 811-822.

Martin El, Ressler KJ, Binder E, Nemeroff CB (2009). The neurobiology of anxiety disorders: brain imaging, genetics, and psychoneuroendocrinology. Psychiatr Clin North Am 32: 549-575.

McEwen BS (1999). Stress and hippocampal plasticity. Annu Rev Neurosci 22: $105-122$.

McEwen BS (2012). The ever-changing brain: cellular and molecular mechanisms for the effects of stressful experiences. Dev Neurobiol 72: 878-890.

McEwen BS, Gianaros PJ (2011). Stress- and allostasis-induced brain plasticity. Annu Rev Med 62: 431-445.

Millstein RA, Holmes A (2007). Effects of repeated maternal separation on anxietyand depression-related phenotypes in different mouse strains. Neurosci Biobehav Rev 31: 3-17.

Molet J, Maras PM, Avishai-Eliner S, Baram TZ (2014). Naturalistic rodent models of chronic early-life stress. Dev Psychobiol 56: 1675-1688.

Molet J, Heins K, Xhuo X, Regev L, Baram TZ, Stern H (2015a). Patterns and entropy rates of neonatal experiences predict adolescent anhedonia. Proc Natl Acad Sci USA In revision.

Molet J, Maras PM, Kinney-Lang E, Chen Y, Ivy AS, Obenaus A, Baram TZ (2015b). Adolescent cognitive vulnerabilities provoked by early-life adversity: Structural and network mechanisms. Biol Psychiatry In review.
Moriceau S, Shionoya K, Jakubs K, Sullivan RM (2009). Early-life stress disrupts attachment learning: the role of amygdala corticosterone, locus ceruleus corticotropin releasing hormone, and olfactory bulb norepinephrine. J Neurosci 29: 15745-15755.

Naninck EF, Hoeijmakers L, Kakava-Georgiadou N, Meesters A, Lazic SE, Lucassen PJ et al (2015). Chronic early life stress alters developmental and adult neurogenesis and impairs cognitive function in mice. Hippocampus 25: 309-928.

Nelson CA 3rd, Bos K, Gunnar MR, Sonuga-Barke EJ (2011). The neurobiological toll of early human deprivation. Monogr Soc Res Child Dev 76: 127-146.

Nelson CA 3rd, Zeanah CH, Fox NA, Marshall PJ, Smyke AT, Guthrie D (2007). Cognitive recovery in socially deprived young children: the Bucharest Early Intervention Project. Science 318: 1937-1940.

$\mathrm{NIH}$ Workgroup (2009). Transformative neurodevelopmental research in mental illness. Results of the NIMH Workgroup. http://www.nimh.nih.gov/about/advisoryboards-and-groups/namhc/neurodevelopment_workgroup_report_33553.pdf.

Nishi M, Horii-Hayashi N, Sasagawa T (2014). Effects of early life adverse experiences on the brain: implications from maternal separation models in rodents. Front Neurosci 8: 166

Oomen CA, Soeters H, Audureau N, Vermunt L, van Hasselt FN, Manders EM et al (2010). Severe early life stress hampers spatial learning and neurogenesis, but improves hippocampal synaptic plasticity and emotional learning under high-stress conditions in adulthood. J Neurosci 30: 6635-6645.

Oitzl MS, Workel JO, Fluttert M, Frösch F, De Kloet ER (2000). Maternal deprivation affects behaviour from youth to senescence: amplification of individual differences in spatial learning and memory in senescent Brown Norway rats. Eur J Neurosci 12: $3771-3780$.

Paus T (2009). Brain Development. In: Lerner RM, Steinberg L (eds). Handbook of Adolescent Psychology. John Wiley \& Sons, Inc.: Hoboken, NJ, USA, pp 95-115.

Pawlak R, Rao BS, Melchor JP, Chattarii S, McEwen B, Strickland S (2005). Tissue plasminogen activator and plasminogen mediate stress-induced decline of neuronal and cognitive functions in the mouse hippocampus. Proc Natl Acad Sci USA 102: 18201-18206.

Pratchett LC, Yehuda R (2011). Foundations of posttraumatic stress disorder: does early life trauma lead to adult posttraumatic stress disorder? Dev Psychopathol 23: 477-491.

Provençal N, Binder EB (2015). The effects of early life stress on the epigenome: from the womb to adulthood and even before. Exp Neurol 268: 10-20.

Radley JJ, Rocher AB, Rodriguez A, Ehlenberger DB, Dammann M, McEwen BS et al (2008). Repeated stress alters dendritic spine morphology in the rat medial prefrontal cortex. J Comp Neurol 507: 1141-1150.

Raineki C, Holman PJ, Debiec J, Bugg M, Beasley A, Sullivan RM (2010). Functional emergence of the hippocampus in context fear learning in infant rats. Hippocampus 20: 1037-1046.

Raineki C, Cortes MR, Belnoue L, Sullivan RM (2012). Effects of early-life abuse differ across development: infant social behavior deficits are followed by adolescent depressive-like behaviors mediated by the amygdala. J Neurosci 32: 7758-7765.

Refojo D, Schweizer M, Kuehne C, Ehrenberg S, Thoeringer C, Vogl AM et al (2011). Glutamatergic and dopaminergic neurons mediate anxiogenic and anxiolytic effects of CRHR1. Science 333: 1903-1907.

Regev L, Baram TZ (2014). Corticotropin releasing factor in neuroplasticity. Front Neuroendocrinol 35: 171-179.

Rice CJ, Sandman CA, Lenjavi MR, Baram TZ (2008). A novel mouse model for acute and long-lasting consequences of early life stress. Endocrinology 149: 4892-4900.

Rincón-Cortés M, Sullivan RM (2014). Early life trauma and attachment: immediate and enduring effects on neurobehavioral and stress axis development. Front Endocrinol (Lausanne) 5: 33.

Roozendaal B, Brunson KL, Holloway BL, McGaugh JL, Baram TZ (2002). Involvement of stress-released corticotropin-releasing hormone in the basolateral amygdala in regulating memory consolidation. Proc Natl Acad Sci USA 99: 13908-13913.

Roth TL, Lubin FD, Funk AJ, Sweatt JD (2009). Lasting epigenetic influence of earlylife adversity on the BDNF gene. Biol Psychiatry 65: 760-769.

Sandi C, Haller J (2015). Stress and the social brain: behavioural effects and neurobiological mechanisms. Nat Rev Neurosci 16: 290-304.

Schmidt MV, Wang XD, Meijer OC (2011). Early life stress paradigms in rodents: potential animal models of depression? Psychopharmacology (Berl) 214: 131-140.

Schwabe L, Joëls M, Roozendaal B, Wolf OT, Oitzl MS (2011). Stress effects on memory: an update and integration. Neurosci Biobehav Rev 36: 1740-1749.

Seay B, Hansen E, Harlow HF (1962). Mother-infant separation in monkeys. J Child Psychol Psychiatry 3: 123-132.

Segal M (2010). Dendritic spines, synaptic plasticity and neuronal survival: activity shapes dendritic spines to enhance neuronal viability. Eur J Neurosci 31: 2178-2184. 
Sheridan MA, McLaughlin KA (2014). Dimensions of early experience and neural development: deprivation and threat. Trends Cogn Sci 18: 580-585.

Shonkoff JP (2011). Protecting brains, not simply stimulating minds. Science 333: 982-983.

Sullivan PG, Dubé C, Dorenbos K, Steward O, Baram TZ (2003). Mitochondrial uncoupling protein-2 protects the immature brain from excitotoxic neuronal death. Ann Neurol 53: 711-717.

Szyf M (2015). Epigenetics, a key for unlocking complex CNS disorders? Therapeutic implications. Eur Neuropsychopharmacol 25: 682-702.

Turecki G (2014). The molecular bases of the suicidal brain. Nat Rev Neurosci 15: 802-816.

Ulrich-Lai YM, Herman JP (2009). Neural regulation of endocrine and autonomic stress responses. Nat Rev Neurosci 10: 397-409.

Uysal N, Ozdemir D, Dayi A, Yalaz G, Baltaci AK, Bediz CS (2005). Effects of maternal deprivation on melatonin production and cognition in adolescent male and female rats. Neuro Endocrinol Lett 26: 555-560.

Van Bockstaele EJ, Valentino RJ (2013). Neuropeptide regulation of the locus coeruleus and opiate-induced plasticity of stress responses. Adv Pharmacol 68: 405-420.

van Oers HJ, De Kloet ER, Levine S (1998a). Early vs. late maternal deprivation differentially alters the endocrine and hypothalamic responses to stress. Brain Res Dev Brain Res 111: 245-252.

van Oers HJ, de Kloet ER, Whelan T, Levine S (1998b). Maternal deprivation effect on the infant's neural stress markers is reversed by tactile stimulation and feeding but not by suppressing corticosterone. J Neurosci 18: 10171-10179.

van Os J, Kenis G, Rutten BP (2010). The environment and schizophrenia. Nature 468: 203-212.
Van Pett K, Viau V, Bittencourt JC, Chan RK, Li HY, Arias C et al (2000). Distribution of mRNAs encoding CRF receptors in brain and pituitary of rat and mouse. J Comp Neurol 428: 191-212.

Wang XD, Labermaier C, Holsboer F, Wurst W, Deussing JM, Muller MB et al (2012). Early-life stress-induced anxiety-related behavior in adult mice partially requires forebrain corticotropin-releasing hormone receptor 1. Eur J Neurosci 36: 2360-2367.

Wang XD, Rammes G, Kraev I, Wolf M, Liebl C, Scharf SH et al (2011). Forebrain CRF(1) modulates early-life stress-programmed cognitive deficits. J Neurosci 31: 13625-13634.

Wang XD, Su YA, Wagner KV, Avrabos C, Scharf SH, Hartmann J et al (2013). Nectin-3 links CRHR1 signaling to stress-induced memory deficits and spine loss. Nat Neurosci 16: 706-713.

Wilson RS, Scherr PA, Bienias JL, Mendes de Leon CF, Everson-Rose SA et al (2005). Socioeconomic characteristics of the community in childhood and cognition in old age. Exp Aging Res 31: 393-407.

Yang XD, Liao XM, Uribe-Mariño A, Liu R, Xie XM, Jia J et al (2015). Stress during a critical postnatal period induces region-specific structural abnormalities and dysfunction of the prefrontal cortex via CRF1. Neuropsychopharmacology 40: 1203-1215.

Yi SJ, Baram TZ (1994). Corticotropin-releasing hormone mediates the response to cold stress in the neonatal rat without compensatory enhancement of the peptide's gene expression. Endocrinology 135: 2364-2368.

Zoladz PR, Diamond DM (2008). Linear and non-linear dose-response functions reveal a hermetic relationship between stress and learning. Dose Response 7 : $132-148$. 